\title{
THE PRACTICALITY OF ELECTRONIC MONITORING PRAKERIN BASED ON ANDROID SYSTEM IN VOCATIONAL HIGH SCHOOL STUDENT INTERNSHIPS
}

Sutikno $^{1^{*}}$, Baedhowi ${ }^{2}$, Siswandari $^{3}$, Roemintoyo $^{4}$

${ }^{1}$ Student of Science Education Doctorate Program, Universitas Sebelas Maret, J1. Ir. Sutami 36A, Surakarta, Indonesia;

${ }^{2,3,4}$ Lecturers of Faculty Education and Teacher Training, Universitas Sebelas Maret, J1. Ir. Sutami 36A, Surakarta, Indonesia.

Email: ${ }^{1 *}$ sutiknofaras@student.uns.ac.id, ${ }^{2}$ bdhwi@yahoo.co.id, ${ }^{3}$ siswandari@staff.uns.ac.id, ${ }^{4}$ roemintoyo@yahoo.co.id Article History: Received on $24^{\text {th }}$ March 2020, Revised on $24^{\text {th }}$ April 2020, Published on $16^{\text {th }}$ May 2020

\section{Abstract}

Purpose of the study: This research aims to find out 1) the facts of electronic internship monitoring and 2) the practicality of using android-based electronic monitoring in the vocational student internship program.

Methodology: The method applied in this research is a descriptive qualitative thorough survey on the implementation of electronic internship training. The respondents were the teachers at Public Vocational High School 1 Mondokan as the supervisors of the student internship program. The instrument used was a questionnaire for the implementation of $e$-monPrakerin. The data analysis technique used descriptive analysis with percentages.

Main findings: The results of the research show that Android-based electronic monitoring of internship. 1) facilitates monitoring; 2) is practical, with very high criteria (83,08\%). An electronic monitoring internship based on Android is more practical according to the response from the internship supervisor.

The implication of this study: The concept of electronic monitoring is easily understood by the supervisor. There are very few errors in using the features. The internship monitoring application the supervisor has already understood a guide before guiding the students.

Novelty/Originality of this study: The novelty of this study lies in the strategy of monitoring electronically, this provides new insight in apprenticeship supervision compared to conventional apprenticeship supervision. Conventional monitoring is considered less effective because there are weaknesses.

Keywords: E-Monprakerin, Internship, Vocational, Practicality, Monitoring, Supervisor.

\section{INTRODUCTION}

The development of competent and highly competitive human resources is the main issue in the global competition in the industrial era 4.0. The national manufacturing sector must be well-prepared to make major changes in facing the fourth revolution of industry or Industry 4.0. Consequently, new approaches and skills are needed to build innovative and sustainable production systems (Kemenperin, 2018).

The effect of the revolution of industry 4.0 is the increased production efficiency because it uses digital technology and automation, as well as changes in the work composition. The government emphasizes five industries that focus on implementing industry 4.0 in Indonesia: food and beverage, textile, automotive, electronic, and chemical industries (Bartodziej, 2017; Kemenperin, 2017; Kompas, 2018; Ustundag \& Cevikcan, 2018). To prepare an innovative workforce capable of competing in the revolution of industry 4.0, the implementation of quality education needs to be carried out. The ideal results of vocational high school alumni are medium-sized workers who are ready to use in business and industry (Muhammad, 2016).

To support conformity with the industry, one way is done by industrial work practices. The government initiated the application of appropriate vocational education to link and match between vocational high schools and industries. The development of the program also prepares skilled workers who are ready to be used in the industry with a target of reaching one million people in 2019 (Kemenperin, 2017; Kompas, 2018). The internship program with industry as a form of student competency improvement program is carried out under their fields of expertise (Kemenaker, 2016; Kemendikbud, 2014). This program is conducted to make students get to know the industry first and to stimulate them to study harder. Students will experience more activities in the industry (Shin, Lee, Ahn, \& Jung, 2013). The internship is expected to produce workers who have the professional expertise, improve and strengthen the link and match between schools/vocational training institutions and the world of work, improve the efficiency of the education process and training of the professional-quality workforce, and recognize and reward work experience as part of the process education (MercaderTrejo, López, Granada, Hernández, \& Basurto, 2016).

During the internship implementation, monitoring is carried out by the school supervisor. Monitoring is needed so that activities can be monitored to identify initial errors immediately. Thus, corrective actions can be taken, which are expected to reduce the greater risk (Subarsono, 2015). The factor that determines the success of the internship program is the involvement of all parties in managing and implementing their respective roles (Sumathi, 2012). In facing the disruption of 
the revolution of the industry 4.0 era, all activities are carried out by utilizing information technology, with lower costs and high-quality levels(Christensen, 1977). Research shows that an internship program is essential and valuable for a student's career. To make an internship program more effective, an entrepreneur must clearly define the project and skills needed, and then try to match students' skills to the project requirements (Kim, \& Bzullak, 2012).

Jones and George explain the control that managers monitor and evaluate whether the strategies and organizational structures work as desired, how they can be improved, and how they should be changed if they don't work (Jones \& George, 2017). The Control function will compare the organization's actual performance with the specified standards, find irregularities, and attempt to take corrective action. Implementation of the existing apprenticeship is located quite far from the school, and there are obstacles related to monitoring industrial work practices in Vocational Schools; there are still many schools that monitor the program conventionally.

\section{NEED FOR THE STUDY AND OBJECTIVES}

Monitoring activities carried out by visiting each industry where students carry out an internship. Managing Prakerin monitoring administration requires changes along with the development of internet users, which shows a very drastic change. Internship monitoring must be more effective and efficient by utilizing technological developments. In the case of this research, monitoring is carried out in the implementation of the internship to monitor the activities of the internship participants so that it runs well.

This study aims to find out 1) the facts of electronic apprenticeship monitoring and 2) the practicality of using android-based electronic monitoring in vocational student internship programs.

\section{LITERATURE REVIEW}

The revolution of industry 4.0 era, industries, and academicians need to exchange experiences for industrial advancement in the future (Abele et al., 2015). The use of social media, digital technology, and communication presents new challenges to meet the objectives of learning programs integrated with work and ensure that students are ready to work now and in the future (Bowen \& Pennaforte, 2017). This can be done by implementing student internships in the industry. With the implementation of internships, students will experience more real activities in the industry (Shin et al., 2013). In addition to this, the internship also increases good competitiveness in entrepreneurship (Sunyoto, Widodo, \& Samsudi, 2018).

The implementation of the internship, the framework for practice is included as a basis for the internship program in the industry (Deschaine \& Jankens, 2017). For the internship to be more effective following the expectations of the implementation of vocational education, its implementation must be managed properly. Management is a process of planning, organizing, coordinating, and controlling resources to achieve goals effectively and efficiently. The management is following education management standards by primary and secondary education units, which include: (1) program planning; (2) implementation of work plans; (3) supervision or evaluation (Kemendikbud, 2007). In the context of supervision, monitoring is carried out on the implementation of internships in the industry.

Monitoring is also an activity aimed at providing information about the causes and effects of a policy being implemented. Monitoring is carried out when a policy is being implemented. Monitoring is needed so that initial errors can be immediately identified, and corrective actions can be taken, thereby reducing the greater risk (Dunn, 2004:277). Monitoring is defined as a cycle of activities that includes collection, review, reporting, and action of information on a process being implemented. Generally, monitoring is used in checking between performance and predetermined targets.

Monitoring has two basic functions that are related, namely compliance and performance. Compliance monitoring is carried out to ensure the suitability of work by agreed standards. The progress which is expected to be achieved is the definition of monitoring the performance. Besides, it covers the measurement of the activity "effect". Thus, the purpose of monitoring is to (a) maintain the policy being implemented by the goals and objectives, (b) find fault as early as possible to reduce the greater risk, and (c) make a modification to the policy if the monitoring results require it.

The use of technology in education is very necessary to increase success (Utama, Sajidan, Nurkamto, \& Wiranto, 2019). Electronic monitoring provides new insights into internship supervision rather than conventional internship supervision. This is the right step to increase the effectiveness of internship monitoring (Jeske \& Axtell, 2014). To succeed in the administration of the monitoring process, a framework that combines good practice with new literature and standards is needed (Deschaine \& Jankens, 2017). The concept of e-mon Prakerin is designed to be used on smartphone devices (Hamel, Kowang, \& Fei, 2018; Ravisekaran \& Ramakrishnan, 2018). Smartphone usage becomes an exciting thing for teachers and students in competency development (Charoenporn, 2018). In general, teachers and students claim to have a high interest in learning how to operate and use apps on smartphones.

Apps on smartphones can help them in learning and organization processes (Abildinovaa, Alzhanova, Ospanovab, Z. Taybaldievac, \& Pashovkina, 2016; Eligi \& Mwantimwa, 2017; Khan \& Masood, 2015). This concept provides the basis for the development of e-mon Prakerin into the model offered in the internship monitoring. With the increased use of Android, Android-based applications can increase productivity by existing parameters (Kleinwort, Semm, Falger, \& Zaeh, 2018). Applications with Android smartphones are very helpful in the process of monitoring activities. This is evident with the increasing number of monitoring applications based on the Android operating system (Rupavathy, M.J., \& Nivedhitha, 
2018).

The $e$-mon Prakerin models can maximize the performance of industrial work practices (internship) of students (Sutikno, Baedhowi, Siswandari, \& Roemintoyo, 2019). The implementation of effective industrial work practices must be managed with good administration (Ghavifekr, Afshari, \& Seger, 2013; Renganathan, Ambri Bin Abdul Karim, \& Su Li, 2012). During the internship period, it is not easy for the supervisor to check the progress and status of each student regularly. Besides, relatively short internships are a problem for students to gain experience in the industry (Shin et al., 2013). Jones \& George state that advances in information technology make it possible to make a big leap by gathering information that is more timely, complete, relevant, and of high quality and using it in a more effective way (Jones \& George, 2017).

Information technology is applied to the management of information which is currently an important part because (1) the increase in complexity of the task of management, (2) the influence of the international economy (globalization), (3) the need for faster response time (response time), (4) pressure due to business competition. (Sutarman, 2009). Effectiveness is closely related to technical rationality, often measured in units of product or service or financial value (Dunn, 2004).

Effectiveness refers to whether the given alternative results in the achievement of the outcome (effect) of the action, namely the goal. Effectiveness can be interpreted as using a certain amount of resources, facilities, and infrastructure consciously set in advance to produce several jobs on time (Abdulrahmat, 2003). Effectiveness can also be interpreted as the level of success that can be achieved in a particular way or business by the objectives to be achieved. Measuring the effectiveness of an internship program may not be easy, but studies are needed to improve the internship program in general.

The previous research measured perceived effectiveness or satisfaction, but not the actual effectiveness of the internship program. Various parties involved in the internship program (students, entrepreneurs, recruiters, and universities) may have different goals which result in different success definition. Thus, the effectiveness of an internship program may be measured in different dimensions. It may not be easy to measure and integrate the effectiveness of the internship program (Kim et al., 2012).

\section{METHODS}

\section{Research Design}

The method used in this study is a descriptive survey with product trial design in the implementation of electronic internship monitoring. Strategies for electronic monitoring provide new insights into apprenticeship supervision compared to conventional monitoring. Conventional monitoring is considered less effective because there are weaknesses.

\section{Research Sample}

The respondents were the teachers at Public Vocational High School 1 Mondokan as the supervisors of the student internship program. The sample was chosen because of SMK Negeri 1 Mondokan as a provider of educational services, which is always committed to improving the quality of service to all stakeholders. In the face of competition from the Global MEA (ASEAN Economic Community) or AEC (ASEAN Economic Comunity), fast and accurate information is needed so that graduates of SMK Negeri 1 Mondokan are ready to step into the industrial world in selecting the sample for the research, it was based on the standard of students of vocational high school at the twelfth or last grade which was conducting job training practice as his/ her major.

\section{Instrument and Procedures}

The assessment of product practicality is shown using monitoring application and the results of teachers' responses to the use of the application in the form of quantitative data from the scores of each criterion. The instrument used is a questionnaire for the implementation of e-mon Prakerin. The observation sheet consists of 13 question items with the answers to Strongly Agree, Agree, Neutral, Disagree, and Strongly Disagree.

The indicators of the user aspect above are divided into two categories, namely: 1) Practical indicators including ease of learning features, ease of remembering functions and prevention of errors; 2) Effectiveness including indicators of speed and user satisfaction. This test is intended to measure how the quality of information systems is produced so that the practicality and effectiveness of the system being developed can be identified (Juradin, M, \& Purnamawati, 2018).

The practicality of monitoring can be seen through observation on the internship supervisor with a questionnaire that includes cost-saving, usefulness, ease of learning the application, and ease of use. Indicator plans are easy tools to assist the monitoring of time. The plan indicator opens more chances for a) better indicators, b) indicators specifications, c) arrange a prudent time table in collecting the data, and d) select methods for gathering the data. It is seen to be more efficient. If this plan is reflected in the work plan, the staff and other resources have sufficient time to implement it (Mercy, 2005:25). The indicator of monitoring practicality can be seen in Table 1. 
Table 1: Observation result of electronic internship monitoring practicality

\begin{tabular}{|c|c|c|}
\hline Dimension & Indicator & Statement \\
\hline Cost-saving & 1. Cheap financing & $\begin{array}{l}\text { I take the students directly to the place of } \\
\text { internship. } \\
\text { I monitor the internship activities from the } \\
\text { workplace. }\end{array}$ \\
\hline Usefulness & $\begin{array}{l}\text { 2. The app facilitates the mapping of } \\
\text { internship participants. } \\
\text { 3. The app facilitates internship } \\
\text { monitoring. } \\
\text { 4. It can be used for monitoring } \\
\text { internship. }\end{array}$ & $\begin{array}{l}\text { The internship is a school program that is part } \\
\text { of the curriculum. } \\
\text { The internship planning uses electronic media. } \\
\text { I monitor internship students every day. } \\
\text { I easily recap the attendance of internship } \\
\text { students every time. }\end{array}$ \\
\hline $\begin{array}{l}\text { Ease of learning the } \\
\text { application }\end{array}$ & $\begin{array}{l}\text { 5. I know the use of the application } \\
\text { menu. } \\
\text { 6. It is easily informed to others. } \\
\text { 7. I know the features. }\end{array}$ & $\begin{array}{l}\text { The monitoring application menu is difficult to } \\
\text { understand. } \\
\text { I ask a colleague to use the application. } \\
\text { If there are difficulties, I open the existing user } \\
\text { guide. } \\
\text { The monitoring features are easy to } \\
\text { understand. }\end{array}$ \\
\hline $\begin{array}{l}\text { Ease of } \\
\text { use/prevention of } \\
\text { errors }\end{array}$ & $\begin{array}{l}\text { 8. I know the concept of electronic } \\
\text { monitoring. } \\
\text { 9. I know the errors in using the } \\
\text { features. }\end{array}$ & $\begin{array}{l}\text { I have read/understood the electronic } \\
\text { internship monitoring guide before guiding } \\
\text { students } \\
\text { I have given debriefing for the electronic } \\
\text { internship monitoring material. } \\
\text { I provide a guide to electronic internship } \\
\text { monitoring. }\end{array}$ \\
\hline
\end{tabular}

Source: (Mercy, 2005)

\section{Data Analysis}

The data analysis technique used descriptive analysis with percentages. Practicality is determined by calculating scores from each aspect and changing the score to a value with predetermined criteria. References to change the score to scale five can be seen in Table 2.

Table 2: Conversion score assessment statement of practical quality score

\begin{tabular}{ll}
\hline Score Percentage (Ps) & Category \\
\hline $0 \leq$ Ps $\leq 20$ & Not good \\
$21 \leq$ Ps $\leq 40$ & Not so good \\
$41 \leq$ Ps $\leq 60$ & Quite good \\
$61 \leq$ Ps $\leq 80$ & Good \\
$81 \leq$ Ps $\leq 100$ & Very Good \\
\hline
\end{tabular}

Source: (Juradin, M, \& Purnamawati, 2018)

\section{RESULT AND DISCUSSION}

An effective monitoring system has several criteria, namely: 1) Focusing on only some indicators. It is important to distinguish between indicators for outputs/activities and objectives. If you have a complete work plan, it will be easy to track the progress on larger results. However, it is also important that we monitor the progress towards our goals. We need to find one or two indicators per target that show our progress and set a schedule for monitoring only once or twice. 2) Monitoring regulated in the work plan. It is very difficult to take time for the entire monitoring cycle (collection, reflection, decision making, and reporting) unless one is responsible from the start through a work plan and budget. 3) Collecting initial data. For longer programs/projects, collecting basic data can save a lot of time. In addition to helping to show success over time, initial data collection is a test of indicators and time commitment at the outset providing information about the ease of monitoring selected indicators. 4) Using the indicator plan to plan information needs.

Observations were performed by testing on internship supervisors. They gave responses to the observation sheet provided. The observation results were converted into percentages. The survey results using the observation sheet can be 
seen in figure 1.

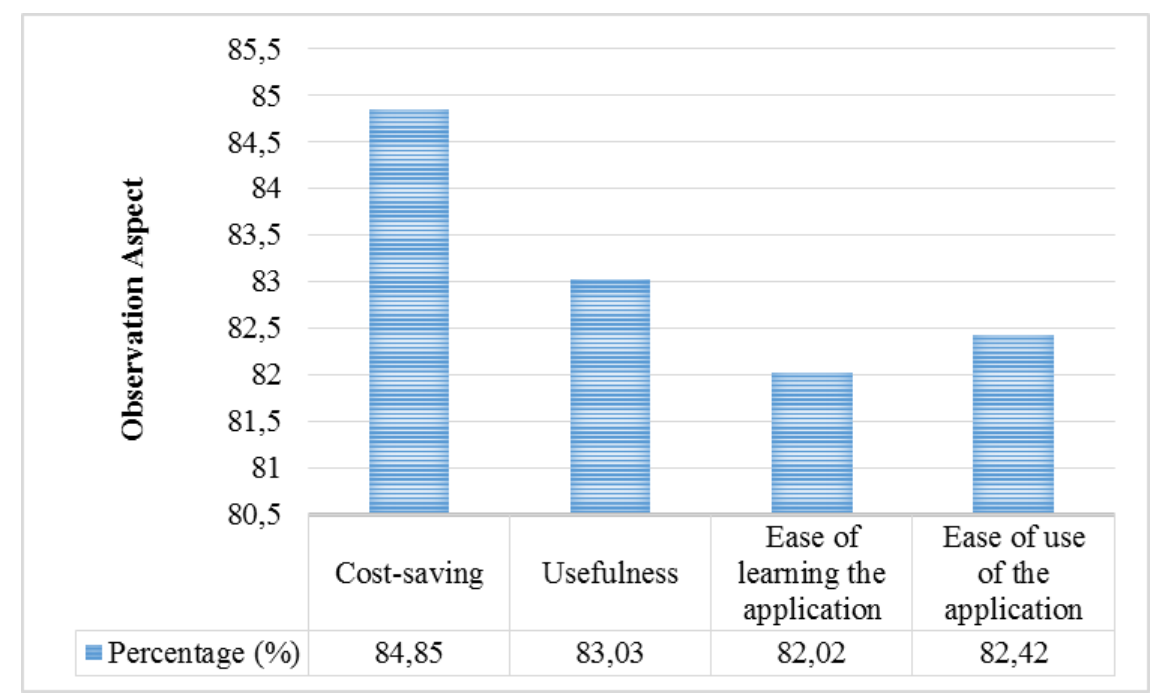

Figure 1: Observation result of electronic internship monitoring practicality

Figure 1 shows that the average result of the observation of the electronic internship monitoring practicality is $83.08 \%$ included in the very good category. This means that electronic internship monitoring is very practical. This practicality can be seen from the aspects of cost saving of $84,85 \%$, the usefulness of $83,03 \%$, ease of learning the application of $82,02 \%$, and ease of use of the application of $82,42 \%$. The observation results are presented in more detail in Table 3.

Table 3: Observation result of electronic internship monitoring practicality

\begin{tabular}{llllll}
\hline Indicator & $\begin{array}{c}\text { Strongly } \\
\text { Agree }\end{array}$ & Agree & Neutral & Disagree & $\begin{array}{l}\text { Strongly } \\
\text { Disagree }\end{array}$ \\
\hline Cheap financing & $54,5 \%$ & $21,2 \%$ & $18,2 \%$ & $6,1 \%$ & $0,0 \%$ \\
\hline $\begin{array}{l}\text { The app facilitates the mapping of } \\
\text { internship participants. }\end{array}$ & $57,6 \%$ & $18,2 \%$ & $12,1 \%$ & $9,1 \%$ & $3,0 \%$ \\
\hline $\begin{array}{l}\text { The app facilitates internship monitoring. } \\
\text { It can be used for monitoring internship. }\end{array}$ & $60,6 \%$ & $15,2 \%$ & $12,1 \%$ & $6,1 \%$ & $6,1 \%$ \\
\hline I know the use of the application menu. & $60,6 \%$ & $12,1 \%$ & $12,1 \%$ & $9,1 \%$ & $6,1 \%$ \\
\hline It is easily informed to others. & $60,6 \%$ & $15,2 \%$ & $9,1 \%$ & $6,1 \%$ & $9,1 \%$ \\
\hline I know the features. & $60,6 \%$ & $12,1 \%$ & $9,1 \%$ & $9,1 \%$ & $9,1 \%$ \\
\hline $\begin{array}{l}\text { I know the concept of electronic } \\
\text { monitoring. }\end{array}$ & $54,5 \%$ & $18,2 \%$ & $12,1 \%$ & $9,1 \%$ & $6,1 \%$ \\
\hline I know the errors in using the features. & $66,7 \%$ & $9,1 \%$ & $9,1 \%$ & $6,1 \%$ & $9,1 \%$ \\
\hline
\end{tabular}

Source: (Data field Results, 2019)

The results showed that the use of electronic monitoring Prakerin based on android systems in vocational high school student was in the very good category. This result is following the development of competent and highly competitive human resources, which have become the main staples in the global competition in the industrial era 4.0. The national manufacturing sector must be prepared to make major changes in the face of the fourth industrial revolution or Industry 4.0. By looking at the observation results of the implementation of the vocational student internship, financing is needed to support the smooth running of the activities. The financing is partly for the travel expenses of the internship supervisor in delivering the participants. It is also needed for the travel expenses of the internship supervisor in conducting monitoring. The observations show that most respondents agree that using electronic applications can save the cost of activities. They agree that travel expenses are not needed when monitoring can be performed from the office where the supervisor works. The data of the student activities can be accessed online by utilizing the internet connection facility in the office. Other supporting activity financing is still needed, but smaller than the implementation of conventional activities.

In terms of the usefulness of electronic monitoring, the app makes it easier to map participants in the internship, to monitor the internship and the activities of the internship participants. The internship is a school program that is part of the curriculum. The internship is planned with electronic media. The supervisor monitors the student's internship every day from electronic applications. This application helps recap the attendance of the student internship every time. It is easy to 
learn how to operate the electronic monitoring application. There are no difficulties in using the application so there is no need to ask other users to overcome them. The user guide is quite helpful in overcoming the difficulties of operating the application. This is because the features in the application are quite easy to recognize.

The use of the electronic monitoring application is very easy with a very good percentage of users. This shows that the concept of electronic monitoring is easily understood by the supervisor. There are very few errors in using the features. The internship monitoring application the supervisor has already understood a guide before guiding the students. The briefing of the electronic internship monitoring material has been given to students to minimize errors in usage.

The monitoring by the supervisor is control during the implementation of the internship. This requires much time, money, and energy in the implementation. By utilizing the existing information technology, the implementation of internship monitoring is more practical (Kim, Belland, \& Walker, 2018). This practicality can see from various aspects that have been partially observed. The use of electronic applications with very high practicality shows that information technology support is a need in the implementation of education (Simin \& Sani, 2015).

\section{CONCLUSION}

Monitoring is one of the activities that support the success of the vocational student internship program. In the revolution of industry 4.0 era, a means for effective and practical monitoring is needed. The electronic model of internship monitoring answers the challenges of industry 4.0 based on information technology so that it can save costs, time, and have high-quality accurate data. By analyzing some of these indicators, electronic internship monitoring uses the application of e-mon Prakerin, with the value of practicality of very good criteria of $83,08 \%$. The measurement of the practicality category includes the aspects of cost-saving $(84,85 \%)$ usefulness $(83,03 \%)$, ease of learning applications $(82,02 \%)$, and ease of use $(82,42 \%)$. The use of the electronic monitoring application is very easy with a very good percentage of users. This shows that the concept of electronic monitoring is easily understood by the supervisor. There are very few errors in using the features. The internship monitoring application the supervisor has already understood a guide before guiding the students. The briefing of the electronic internship monitoring material has been given to students to minimize errors in usage.

\section{LIMITATION AND STUDY FORWARD}

The focus of the study in this research is to see how its effect and effectiveness on applying technological perspective on students' job training of Android system use. This electronic provides fast and easy access for students to assess in terms of the goal and its achievement which is only limited to monitor at the aspects of the internship. It is recommended for future research to make use of the results of this study as the baseline reference to conduct similar monitoring activities which not only limited to the students but also teachers and related stakeholders.

\section{ACKNOWLEDGMENTS}

We want to thank the promoters and all colleagues in the Postgraduate program of Science Education of Universitas Sebelas Maret for all the supports and inputs given especially to the first author in setting up the research framework, second author for data collection and interpretation, third author in revising the conceptual background, and the fourth author in analyzing and presenting the data.

\section{REFERENCES}

1. Abdulrahmat. (2003). Efektivitas Implementasi. Jakarta: Rineka Cipta.

2. Abele, E., Metternich, J., Tisch, M., Chryssolouris, G., Sihn, W., Elmaraghy, H., Ranz, F. (2015). Learning Factories for research, education, and training. Procedia CIRP, 32(Clf), 1-6. https://doi.org/10.1016/j.procir.2015.02.187

3. Abildinovaa, G. M., Alzhanova, N. N., Ospanovab, Z. Taybaldievac, D. S. B., \& Pashovkina, N. O. (2016). Developing a mobile application' educational process remote management system' on the android operating system. Int. J. Environ. Sci. Educ., 11(12), 5128-5145.

4. Bartodziej, C. J. (2017). The Concept Industry 4.0 An Empirical Analysis of Technologies and Applications in Production Logistics. Berlin: Springer. https://doi.org/10.1007/978-3-658-16502-4

5. Bowen, T., \& Pennaforte, A. (2017). The impact of digital communication technologies \& new remote-working cultures on the socialization and work-readiness of individuals in wil programs. International Perspectives on Education and Society, 32, 99-112. https://doi.org/10.1108/S1479-367920170000032006

6. Christensen, C. M.. (1977). The innovator's dilemma: When new technologies cause great firms to fail. Boston: Harvard Business School Press.

7. Charoenporn, P. (2018). Conceptual modeling of QOS' Web Service Framework. International Journal of Engineering \& Technology, 7, 132-136. https://doi.org/10.14419/ijet.v7i3.32.18413

8. Deschaine, M. E., \& Jankens, B. P. (2017). Creating successful and sustainable educational administrative internship experiences. Higher Education, Skills and Work-Based Learning, 7(1), 5-20. https://doi.org/10.1108/HESWBL-02-2016-0008

9. Dunn, W. N. (2004). Public Policy Analysis An Introduction. Upper Saddle River: Pearson Prentice Hall. 
10. Eligi, I., \& Mwantimwa, K. (2017). ICT accessibility and usability to support the learning of visually-impaired students in Tanzania Innosencia Eligi Tanzania Library Services Board. Int. J. Educ. Dev. Using Inf. Commun. Technol., 13(2), 87-102.

11. Ghavifekr, S., Afshari, M., \& Seger, S. S. \& K. (2013). ICT Application for Administration and Management: A Conceptual Review. Procedia - Social and Behavioral Sciences, 103, 1344-1351. https://doi.org/10.1016/j.sbspro.2013.10.705

12. Hamel, N. Binti M., Kowang, T. O., \& Fei, G. C. (2018). A Conceptual Framework for Lean Research and Development. International Journal of Engineering \& Technology, 7, 316-320.

13. Jeske, D., \& Axtell, C. (2014). e-Internships: Prevalence, characteristics, and role of student perspectives. Internet Research, 24(4), 457-473. https://doi.org/10.1108/IntR-11-2012-0226

14. Jones, G. R., \& George, J. M. (2017). Essentials of Contemporary Management. New York: McGraw-Hill Education.

15. Juradin, M, A. M., \& Purnamawati. (2018). Sistem Informasi Monitoring Praktek Kerja Industri Berbasis Web. Makassar.

16. Kemenaker. (2016). Permenaker No. 36 tahun 2016 tentang Pemagangan Dalam Negeri. Jakarta: Kemenaker.

17. Kemendikbud, R. (2007). Permendikbud no. 19 tahun 2007 tentang Standar Pengelolaan Pendidikan.

18. Kemendikbud, RI. (2014). Permendikbud No.60 tahun 2014 tentang Kurikulum 2013 Sekolah Menengah Kejuruan/Madrasah Aliyah Kejuruan.

19. Kemenperin. (2017). Empat Strategi Indonesia Masuk Revolusi Industri Keempat.

20. Kemenperin. (2018). Making Indonesia 4.0. Jakarta: Kemenperin.

21. Khan, F. M. A., \& Masood, M. (2015). The Effectiveness of an Interactive Multimedia Courseware with Cooperative Mastery Approach in Enhancing Higher Order Thinking Skills in Learning Cellular Respiration. Procedia - Social and Behavioral Sciences, 176, 977-984. https://doi.org/10.1016/j.sbspro.2015.01.567

22. Kim, E. B., Kim, K., \& Bzullak, M. (2012). A survey of internship programs for management undergraduates in AACSB-accredited institutions. International Journal of Educational Management, 26(7), 696-709. https://doi.org/10.1108/09513541211263755

23. Kim, N. J., Belland, B. R., \& Walker, A. E. (2018). Effectiveness of Computer-Based Scaffolding in the Context of Problem-Based Learning for Stem Education: Bayesian Meta-analysis. Educational Psychology Review, 30(2), 397-429. https://doi.org/10.1007/s10648-017-9419-1

24. Kleinwort, R., Semm, T., Falger, P. M., \& Zaeh, M. F. (2018). Integration of an Android Application into the Learning Factory for Integration an Android into the Learning Factory for Manufacturing of Optimized Machining. Procedia Manufacturing, (2017). https://doi.org/10.1016/j.promfg.2018.03.153

25. Kompas. (2018). Menuju Revolusi Industri 4.0. Kompas, pp. 1-6.

26. Lau, U. H., \& Tasir, Z. (2018). A Conceptual Framework for Online Authentic Learning to Support Knowledge Construction Among Undergraduates. Int. J. Eng. Technol, 7, 186-191.

27. Mercader-Trejo, F., López, A. R., Granada, G. L., Hernández, L. E. N., \& Basurto, R. H. (2016). Technical internships as a means of acquiring professional skills for future metrologists. Meas. J. Int. Meas. Confed, 84, 1-6. https://doi.org/10.1016/j.measurement.2016.01.040

28. Mercy. (2005). Design, Monitoring, and Evaluation. Mercy Corps.

29. Muhammad, H. (2016). Grand Design Pengembangan Teaching Factory dan Technopark di SMK. Jakarta: Kemendikbud.

30. Ravisekaran, K., \& Ramakrishnan, S. (2018). A Development Framework for Social Media Interaction in Learning Management System. International Journal of Engineering \& Technology, 7, 301-305. https://doi.org/10.14419/ijet.v7i2.13.12787

31. Renganathan, S., Ambri Bin Abdul Karim, Z., \& Su Li, C. (2012). Students' perception of the industrial internship program. Education + Training, 54(2/3), 180-191. https://doi.org/10.1108/00400911211210288

32. Rupavathy, N., M.J., C. M. B., \& Nivedhitha, G. (2018). A mobile application using IoT enabled navigation system for bus riders. International Journal of Engineering \& Technology, 7, 71-74. https://doi.org/10.14419/ijet.v7i1.7.9577

33. Shin, Y.-S., Lee, K.-W., Ahn, J.-S., \& Jung, J.-W. (2013). Development of Internship \& Capstone Design Integrated Program for University-industry Collaboration. Procedia - Social and Behavioral Sciences, 102(IFEE 2012), 386-391. https://doi.org/10.1016/j.sbspro.2013.10.753

34. Simin, G., \& Sani, I. M. (2015). Effectiveness of ICT Integration in Malaysian Schools : A Quantitative Analysis. International Research Journal for Quality in Education, 2(8), 1-12.

35. Subarsono, A. (2015). Analisis Kebijakan Publik. Yogyakarta: Pustaka Pelajar.

36. Sumathi, R. (2012). Students' perception of the industrial internship program. Education + Training, 54(2/3), 180-191. https://doi.org/10.1108/00400911211210288

37. Sunyoto, Widodo, J., \& Samsudi. (2018). Development of the apprenticeship model for vocational school based on entrepreneurship. AIP Conference Proceedings, 1941. ttps://doi.org/10.1063/1.5028097 
38. Sutarman. (2009). Pengantar Teknologi Informasi. Jakarta: Bumi Aksara.

39. Sutikno, Baedhowi, Siswandari, \& Roemintoyo. (2018). A Conceptual of e-monPrakerin Model Internship Management in Vocational High School. (July), 2018. Jember: ICONSME Universitas Jember. https://doi.org/10.1088/1755-1315/243/1/012119

40. Sutikno, Baedhowi, Siswandari, \& Roemintoyo. (2019). Concept of e-mon prakerin model for internship monitoring in vocational high school. IOP Conference Series: Earth and Environmental Science, 243(1). https://doi.org/10.1088/1755-1315/243/1/012119

41. Ustundag, A., \& Cevikcan, E. (2018). Industry 4.0: Managing The Digital Transformation. In Springer Series in Advanced Manufacturing. Birmingham: Springer. https://doi.org/10.1007/978-3-319-57870-5

42. Utama, C., Sajidan, Nurkamto, J., \& Wiranto. (2019). Using TPACK as a framework to analyze the TLC model. Journal of Physics: Conference Series, 1175(1). https://doi.org/10.1088/1742-6596/1175/1/012146 